\title{
KNOWLEDGE AS IDENTITY: AN ESSAY IN GENEALOGY
}

\author{
DUŠAN MARINKOVIĆ ${ }^{1} \&$ DUŠAN RISTIĆ ${ }^{2}$ \\ ${ }^{1}$ University of Novi Sad, Faculty of Philosophy, Department of Sociology, Dr Zorana Đinđića 2, 21000 \\ Novi Sad, Serbia. ORCID: 0000-0002-5352-4719, Email: dusan.marinkovic@ff.uns.ac.rs \\ ${ }^{2}$ Corresponding author: University of Novi Sad, Faculty of Philosophy, Department of Sociology, Dr \\ Zorana Đinđića 2, 21000 Novi Sad, Serbia. ORCID: 0000-0003-2239-6686, Email: risticd@ff.uns.ac.rs
}

\begin{abstract}
In this research, we analyze the nexus between knowledge and identity as a problem of 'sociology of knowledge'. Our aim is to present a genealogical framework with the hypothesis that if we accept that knowledge is a multi-discursive phenomenon, then one way of justifying and stabilizing knowledge in social practices is, through the concept of identity. We single out the problem of locality of discourses and practices and present the "genealogical paths" through which knowledge and identity are intertwined. Furthermore, our attempt is to identify the specific historical relations of knowledge and identity - through the discursive practices and especially in the context of Enlightenment and the claims for "universal knowledge". We recognize these relations within the process of formation of the European identity. KEYWORDS: Genealogy, identity, knowledge, Enlightenment, Europe, Sociology of knowledge
\end{abstract}

\section{INTRODUCTION}

This paper is an attempt of the genealogical analysis of the terms knowledge and identity - terms and concepts that are multi-discursive, diffuse and not easy to define. The main aim of this paper is to situate these terms in the methodological framework of the genealogy and disciplinary framework of the sociology of knowledge. The aim is also to test the hypothesis that - if knowledge is to be approached as a multi-discursive phenomenon, as we do, then it is possible to analyze it as an important part of the (collective) identity formation processes. Furthermore, we claim that this is the process of formation of the European identity - not as an "identity of subjects", but as an "identity of heritage". That is, identity of different cultural, political and other social practices of the creation of knowledge that became the crucial part of the "common 
identity" and history of the Continent - without "measuring” contributions. In this paper, we rely much on the Nietzschean and Foucauldian notion of genealogy. It denotes the critic of the meta-narrative of history in the social sciences and humanities, critique of what Foucault termed "histoire totalisante" - and proposes the analysis of the "history of locality". That is genealogy.

This kind of "localization" of the subject - to the interconnectedness of knowledge and identity - through the research of their "archeological layers", their genealogical paths and practices in the modern history of Europe, also points to the "locality" of the formation of the nexus of identity and knowledge and the social processes of divisions, repressions, exclusions, surveillance, normalization, etc.

Finally, in this paper, we try to explain how the "mangle of discursive practices", knowledge and space, formed the specific historical relations that generated the claims for "universal knowledge". At the same time, at least since the age of Enlightenment, that was part of the processes of formation of the European identity: hence - knowledge as identity.

"Europe" in this paper is not treated as the homogenous space, but more as the "geography of scatteredness" - with the heterogeneous sources. Identity of "the multitudes of Europe" is formed - if we follow the traces of Jacques Le Goff (Le Goff 2005), throughout the Middle Ages. That is, among other things, due to the specific "spatialisation of rationality" and articulation of anonymous and rational knowledge or "universal knowledge".

\section{KNOWLEDGE AND IDENTITY NEXUS}

Depending on the "registers" in which it is defined, knowledge is intertwined with binary oppositions: subjective and objective, individual and collective, ideology and science, legitimate and forbidden, private and public, truth and sense, etc. In the spaces of various binary divisions, knowledge represents a source of doubts as much as of certainties, of truths as much as deceptions, of immanence as much as transcendence, of aposteriority as much as transcendentality. Each register, in which knowledge is "multiplied", indicates its semantic stratification. Hence, we say that knowledge is a multi-discursive phenomenon that is to be found in different discursive practices. Foucault's claim that discourse should not be analyzed with respect to who says what, but in terms of conditions under such statements could have a certain truthful value (Foucault 1981) indicates not only the different sources of discourse as knowledge and power, but also opens the question of the legitimacy of knowledge (as discursive phenomenon) and identity nexus.

Researchers define knowledge in different ways. In sociological terms, it is always a "product", or a consequence of historical and social circumstances in which it was produced. Hence, knowledge as: representations (Durkheim 1995), human interest (Habermas 1972), discourse (Foucault 1981), political knowledge (Said 1979), language (Shotter 1993), identity (Berger 1966), technology (Layton 1974), social imagery (Bloor 1976), culture (McCarthy 1996), political ecology (Weiler 2009), social legitimation (Innerarity 2013), to name a few among many other concepts. All these definitions of knowledge indicate what Foucault (1994a: 389) had already noticed - that no knowledge is shaped without a system of communication, registers, accumulation, shifting. Hence, the recognition of the fact that knowledge and power are closely related is nothing new and it can be found in the works from Marx to Foucault (Weiler 2009).

"Knowledge as..." refers to the relational character of knowledge, i.e. to the fact that the changes in the processes of its legitimization "cannot be explained - at least not exclusively - in terms of the content of knowledge itself" (Weiler 2009: 3; Berger and Luckmann 1991). Knowledge in itself is never autonomous and independent of time, space, institutions and practices in which it is produced.

One of the genealogical lines of the regionalization of knowledge (especially scientific knowledge) is constituted in Europe partly because of the appearance and institutionalization of universities since the twelfth century. When it comes to the European continent, the task of the genealogy of knowledge is to show the historical trajectories of knowledge. That is - how knowledge was constructed throughout European history, although the very term "Europe" and "European identity" are complex (Rifkin 2004) and "are not immutable historical and geographical givens, but rather form a historically and spatially mobile matrix" (Wintle 2013: 10).

Genealogical research is important for us to be able to identify the practices that formed knowledge and identities. The "discursive nexus" of knowledge and identity in this paper does not point to the knowing subject, but rather to the type of practices that connect the terms, or to the practices in which knowledge is part of identity formation processes.

The nexus of knowledge and identity is possible to recognize if we accept the concept of identity that is not essentialist (Delanty and Rumford 2005: 53), but a strategic and positional one. Identity, like knowledge, is also implicated in the fields of binary oppositions. Despite many sets of problems occur when the issue of identity is at question, one of the most important is the problem of its irreducibility (Hall 1996 : 2). Hence, identities are "constructed across different, often intersecting and antagonistic discourses, practices and positions" (Hall 1996: 3-4). Identity, like knowledge, is a multi-discursive phenomenon. Identity is a question of sameness and continuity (id, idem), but also a matter of difference and exclusion. Processes of the formation of identities are established always through the signification and discursive practices that delineate the field of objects and define a legitimate perspective for the object of cognition to be identified, but also for the subjects of knowledge.

Nexus between knowledge and identity brings us the framework of the genealogical analysis, as "history of sense", as well as the spatial or local and regional arrangements and variations of discursive practices. That is also why the geo-epistemic framework of analysis - as the cross-section of research about knowledge, identity and space becomes important. We call this type of genealogical framework a geo-epistemology (Marinković and Ristić 2016) - that is not to say that geo-epistemology is a particula theory or method, but a theoretical and methodological framework in which knowledge is understood as a specificity of space and place where it "comes from". In case of this paper, that is quite a vast space - European continent. Furthermore, this is approach that recognizes that knowledge and discourses are formed in spaces and vice 
versa. In other words, knowledge always has its geo-epistemological function or its spatialized forms - spaces in which it is placed - from quite a "local" institutional level (schools, factories, hospitals, organizations or some other social institution), to the macro-social and macro-territorial levels. Knowledge is in a different way, through space, "distributed" in speeches, statements, institutions, utterances, books, documents or technologies.

We shall see that spatial aspects of the nexus knowledge as identity uncover particularly power infrastructure. If we analyze knowledge "in terms of region, domain, implantation, displacement, transposition" - which are all spatial aspects, we can "capture the process by which knowledge functions as a form of power and disseminates the effects of power" (Foucault 1980: 69). Spatial dimensions of knowledge are particularly important when it comes to the aspect of identity, because it is never unified but increasingly fragmented, fractured, regionalized and fluid.

The geo-epistemology of identities identifies their anchorage in language, discourse and abstract concepts that have certain geo-locations, either physical or imaginary places of origin. Since identities are constructed within discourse and since "identities have a narrative dimension" (Delanty and Rumford 2005: 51), they could be analyzed through the specific "enunciative strategies", "within the play of specific modalities of power". Identities are "thus more the product of the marking of difference and exclusion, than they are the sign of an identical, naturally-constituted unity" (Hall 1996: 4). Their spatiality should be understood through discursive practices and knowledge/ power/space relations.

\section{GENEALOGY OF KNOWLEDGE AND THE EUROPEAN IDENTITY}

Opposite to historicist consciousness which strives to establish the "hegemony of universality" and necessity of the development of the world historical process or "totalizing history" of the advancement of the mind - like in Hegelian terms - genealogy is not only the "history" of descent (Foucault 1984a: 90). It has a resonance of the "provinciality". Opposite to the light of the sun which shines on world history (Hegel 2001: 430-433), genealogy is grey (Foucault 1984a: 76). Opposite to the great path of necessity, genealogy offers understanding of the meanders or capillary polymorphous contingencies - events and aleatories - statements. Wasn’t Foucault’s (1988a: 10) archaeology and genealogy resented for this very "provinciality", localism and "parochiality"? There seems to be a need for spatial distance, another geography, in order for the "provincial" history of Europe to be seen (Chakrabarty 2008). Opposite to the Hegelian mind that is objectivized in the state, genealogy offer the "paths" in which practices "move" and "paths" that "universalize" only local type of rationality and knowledge.

These are the Nietzschean genealogical paths of Herkunft, because genealogy is always about a "series of historical analyses" (Foucault 1978: 8). It leads to the materiality of local practices, to empirical insights that are stored in archaeological layers. Genealogy traces human practices that are mediated by power and knowledge. This is "the case of a society" (Foucault 1978: 8). This is simultaneously, in many cases, a problem of constant intersection of genealogical paths in which discourses and knowledges move towards "their" practices.

Such a genealogy, for instance, could identify how medical perception was transformed into medical gaze and the new practices of power and knowledge (Foucault 2003); how psychiatric practices of "liberation" of mad were transformed into psychiatric power (Foucault 2006a; 2006b); how practices of surveillance and punishment over the body became a general panoptical and disciplinary model in the society (Foucault 1994a; 1995); how Victorian knowledge of sexuality became the form of discipline in medical and moral practices (Foucault 1978); how the growth of wealth became the subject of political economy and how the aleatory aspect of speech was regulated in discourse (Foucault 1981: 62). Finally, “locality of practices”, discourses and knowledge participate in the formation of what, at least since the age of Enlightenment, could be called "European knowledge" and "European identity".

In the research of knowledge as identity, genealogy should follow the traces of the "local" regions - just as Foucault did in his research - by identifying the emergence of prisons, clinics, madhouses, asylums, schools, universities, factories. Even when the genealogy of "local paths" leads us to a certain epoch, to the Enlightenment- we can open the problem of "archaeological stratification" of knowledge and identity (Foucault 1978: 3-13). This kind of research does not "arrive" at the Hegelian "freedom of subjectivity", but at the locally or regionally constructed subjectivities that are generalized, or attempted to be - with some "instruments" of power, like institutions.

One possible genealogical analysis of (scientific) knowledge should look carefully throughout the practices of development of universities across Europe - since the "public", "anonymous" and "objectified" knowledge that we call science is constituted, at least in part, through the processes of institutionalization of the universities during the $12^{\text {th }}$ century in Italy and later on in other countries of Europe. Ideal of "public knowledge" was, according to Peter Burke (2004: 83), visible in the early modern period in European history, but "the question of what kinds of knowledge ought to be made public was a controversial one and is answered in different ways in different generations and in different parts of Europe".

The other genealogical aspect leads to the Enlightenment and the rise of the practices of disciplining knowledge in different social fields. The Enlightenment is in this sense the "infrastructure" of common European knowledge as identity. Though, "the Aufklärung has been a very important phase in our history and in the development of political technology, we have to refer to much more remote processes if we want to understand how we have been trapped in our own history" (Foucault 1982: 210).

Knowledge has been firmly connected with science for many centuries, and science converted knowledge into the "regime of the truth" by different, "local" practices and institutions - in order to monopolize it, globalize it and universalize it. However, we should not forget that the term "knowledge" includes not just the scientific knowledge, but different types of knowledge in past and present societies (Berger and Luckmann 1991). Knowledge is not just the knowledge of truth in the scientific terms, but also the knowledge of sense - because it secures basic interpretative and symbolic schemes for what people call social reality (Ristić and Marinković 2016). Although this claim about 
knowledge should ensure that we see knowledge "everywhere", genealogy helps us to narrow down the means of its analysis. Genealogical method and the research of the "regionalization" of knowledge aims to explain how a certain kind of knowledge is constructed, what is acceptable way of getting at reality and how knowledge claims are justified and stabilized in social practices (Livingstone 2003: 88)

When this genealogical locality is placed in a wider historical context of the creation of a unique space of knowledge and identity, it leads us to the history of Europe. That is why French historians of the Annales School - these historians-geographers of Europe, had to relinquish the old history of dates, events and grand scales. Europe is many things, all of them with their own, peculiar histories: An Aborted Europe; A Dream of Europe; Potential Europe; Feudal Europe; The 'Fine' Europe (Le Goff 2005). That is why there is the Europe of wine and beer, the Europe of the Latin and Byzantine world, the Europe of land and sea, the Europe of olives and lavender and the Europe of salted cod fish and amber, the Europe of the inquisition and the Europe of science, the Europe of divided Christians, the Europe of Hungarians, Huns, Vikings, Muslims (Bloch 2004 3) and the Europe of "Europeans" and Europe of "Others", the Europe of towns and villages, the Europe of the antique and modern concept of the West, etc.

The Europe of myths and the Europe of logos have "matured" in the processes of anchoring its identity and knowledge in Enlightenment. The geography of the Enlightenment was primarily the geography of "microscopic" localities (Clark, Golinski, and Schaffer 1999: 26): scattered libraries, salons, observatories, archives, clubs, societies, universities, and schools. The important question is not only Was ist Aufklärung? (Kant 1784), but also where was the Enlightenment. The geographical and cultural span of the Enlightenment stretched from the Baltic Lutherans through French artillery engineers, English instrument makers, sentimental novelists, Dutch patricians and country girls, political arithmeticians to Prussian metaphysicians (Daston 1999: 495). When at the turn of the epochs - during the sixteenth century - process of "urban rooting" of scattered geographical localities was accelerated, that was at the same time part of the process of the formation of the future urban identity of Europe. Locating knowledge (Peter Burke 2004: 53) in towns- was actually the anchoring of local identities that had been "floating" until then: "The enlightened, whether resident in London or Königsberg, Paris or St. Petersburg... imagined themselves as comrades in a common undertaking, the material and moral improvement of the human estate" (Daston 1999: 499).

But an important genealogical question remains open: "In what is given to us as universal, necessary, obligatory, what place is occupied by whatever is singular, contingent, and the product of arbitrary constraints?" (Foucault 1984b: 45). Isn't this the quest for the same genealogical paths of the modernity that Max Weber already "traveled" - as a representative of a whole Nietzschean generation (Loader 2001). That quest led Weber to the insight into unanticipated, yet global consequences of a "parochial” ethics and a local rationality - the Protestantism (Weber 2005). Weber's question also opened the problem of "universal history" and universal significance and value (Weber 2005: xxviii).

Just like in Plato's allegory of the Cave, Europeans could for a long time observe only the shadows produced by the light that came from the "Islamic shores" of the Mediterranean: from Alexandria, Beirut and, further on, from Baghdad, Teheran and Damascus. It is what Marc Bloch (2004: 3) noted a long time ago: "For a long period neither Gaul nor Italy, among their poor cities, had anything to offer which approached the splendor of Baghdad or Córdoba" (but see: Le Goff 1993). However, the sixteenth and seventeenth centuries represent a deep break, a cut, a geo-epistemological break. In this break, distancing, acceleration, "crack" - in that "spatial landscape that stretched from the end of the thirteenth to the dawn of the eighteenth century" (Delumeau 2007) - we search for the origins of Europe, its knowledge and identities.

It seems that Europe "made" its knowledge and identities from various kinds of accidents: from diseases, plague, leprosy, heresies, wars, banishments, invasions, intrusions. From wars it "made" technology, tactics, strategies, territories, geography, cartography and maps; from diseases it "made" medicine, hygiene, surveillance, discipline, body; from intrusions and invasions it "made" anthropology - knowledge of the Other; from heresy it "made" the inquisition, confessions and professions, measures, investigations, interrogations; from repentance it "made" the analysis of verbal confession (Foucault 1994d: 126); from punishment it "made" prisons and ghettos; from leprosy it "made" a binary division, separation; from the plague it "made" control, surveillance and practices of classification (Elden 2003); from the lack of hygiene it "made" population, politics, police: "It is not possible to see European history as the progressive embodiment of a great unifying idea since ideas are themselves product of history... The European idea has been more the product of conflict than consensus” (Delanty 1995: 2). We often forget that the (local) grandeur of Renaissance also emerged in the middle of a great disease - the plague. Hunger, deprivation and modesty were, at the time, a way of life for the whole Mediterranean (Braudel 1995: 57). The "body" of the Renaissance was thus deeply cut with a great mortality and lack of hygiene of individuals, whole families and towns, cut by diseases and still undeveloped medicine, cut by invasions from the east and south, political instabilities and local conflicts and wars.

For a long time identity has been nomadic, or "too local". This is a long period of hamlets, remote and scattered villages. Until the eleventh, perhaps even the twelfth century, Europe was still a geography of wild forests, overgrown fields, dangerous rivers, even more dangerous seas, hardly passable mountains; this was still a geography of overgrown Roman roads, collapsed bridges, torn down theaters and amphitheaters. Wanderers, vagabonds, these are "typical representatives of the time" (Le Goff 2009 61 ) - the time that only hinted at a demographic growth, more intensive agriculture, restoration of towns, crafts, skills and trade. The time when the majority of wandering would be stopped in order for people, nations and their cultures to be created along with new regional particularities, and finally, only when the pace of centennial migrations was stopped, an infrastructure would be created of a static mentality and identity. A "mindless load" wandered across Europe at the end of the middle ages on its "symbolic voyage" (Foucault 2006a: 8). Lepers wandered - they would be rooted by the asylum; the sick wandered - they would be rooted by the clinic and the gaze of medical knowledge, with the "birth of the clinic" (Foucault 2003). The exiled, outlaws, robbers 
and beggars wandered - they would be rooted by the prison (Foucault 1995), through a new optics of surveillance and technology of punishment, before the new separations, classifications and spatializations (Foucault 2006a). First medieval "intellectuals" wandered, that roaming band that "severely criticized the society” (Le Goff 2009: 61) they would be anchored by colleges and universities. Merchants and dealers wandered - they would be anchored by the first permanent fairs and markets. They would also be stopped at the gates of towns, anchored by the global market. Craftsmen with their skills wandered - they would be first anchored by guilds and later, along with all the others, the capitalist way of manufacturing - they would be anchored by the division of labor and social classes. They would be anchored by the ideologies of social classes (Bufton 2004) and spatialized by workers' settlements and suburbias. Cervantes' Don Quixote also wandered and then appeared as an ordinary man - Alonso Quixano - he was anchored by the first modern novel (Foucault 2002: 54) because his wanderings in vain "form the boundary: they mark the end of the old interplay between resemblance and signs and contain the beginnings of new relations" (Foucault 2002: 51). It is a paradigm of the common identity in Europe at the turn of the epochs. Don Quixote is the last attempt to attribute meaning to the world, knowledge that can no longer be understood in the matrix of "old" meanings of closeness - locality and parochiality. This is identity stretched between the "dying" knowledge of the sense and the "newborn" knowledge of the truth - a science. Don Quixote - he shows a dangerous play of identities. A danger of "liberated subjectivity" that is free to chose identities - but the epoch has already offered a new repertoire in which old identities can no longer play on the stage of the new public, except in psychiatry: "And every episode, every decision, every exploit will be yet another sign that Don Quixote is a true likeness of all the signs that he has traced from his book" (Foucault 2002: 52), not knowing that it is the end of an epoch, the end of the "interplay" of similarity in which identity is pre-given, fixed, without a visible change towards something different: "Don Quixote is not a man given to extravagance, but rather a diligent pilgrim breaking his journey before all the marks of similitude. He is the hero of the Same" (Foucault 2002: 51) - a hero of the space which does not cross borders of an Iberian parochiality.

Various strangers, foreigners and refugees wandered. They were stopped at the gates of new towns or were anchored by the borders of nation-states - people were anchored by citizenship, a new and until then unknown form of belonging. Finally, all these wanderers would be anchored by a new form of multiple belonging - identity. For a long time identity was located in the spaces of proximity and familiarity where social relationships of a certain and recognizable world were reproduced. The moment when an epoch of great distances and new borders was created, the man began his quest for the answer to the question Who am I? and "asking 'who you are' makes sense to you only once you believe that you can be someone other than you are" (Bauman 2004: 19).

For a long time others' knowledge wandered: first across vast Mediterranean peninsulas, then across the Continent. The geo-epistemology of these large peninsulas was at the same time the genealogy of increasing inter-dependencies between Europe and the wider world (Smith 2013), non-European or still non-European localities which managed to become not only European, but universal. Across the Balkan Peninsula to its future continental center came the logos of Greek philosophy, but in the waves from the East across it also came distant mythologies. Across the Apennine Peninsula all the way to the "continent" arrived art and ancient technologies that were later transformed into Renaissance. Across the Iberian Peninsula came Arabic translations of Greek philosophy and medicine. But also the Arabic cartography, technology and navigational instruments without which it would not be possible to discover the New World: "Baghdad played an important part in cultural transmission through the translation and diffusion of Greek medical and scientific works. The mathematical writings of Archimedes, the astronomical and geographical treatises of Ptolemy, and various Aristotelian philosophical texts in translation all spread west from Baghdad to Córdoba” (Livingstone 2003: 91).

Genealogy of European knowledge, whose paths move across the scattered European geography, reveals that knowledge is made of polymorphous genealogy. The sources of knowledge are more heterogeneous than it is believed. The provenances of European knowledge came from "far away". Through its epochs, from Renaissance to Enlightenment, the geography of Europe managed to transform this polymorphous knowledge that arrived from the depths of history and from distance into anonymous and universal knowledge available to everyone - science. This was its great "offer" to all kinds of parochiality: "The universal communication of knowledge and the infinite free exchange of discourses in Europe, against the monopolized and secret knowledge of Oriental tyranny" (Foucault 1981:62).

Throughout history of its knowledge, Europe shaped a representation of itself. Only through history and a universal type of knowledge - science - the product of its politics of universal rationality and practices, it looked at its own and Others' identity. This was a gaze that transformed, long after the fall of the Roman Empire, overgrown fields and forests into Europe. The gaze that went over old Roman borders and turned spaces beyond them into something "European".

\section{CONCLUSION}

Although they encounter in many fields, knowledge and identity primarily "meet" in the field of sense. Just like knowledge, identity is about attribution of meaning and "description" of experience. However, regardless of whether we are talking about the truth or sense, both knowledge and identity were "born" in a struggle: in the strategies of imposing what is considered to be the truth and sense, in the tactics of resistance to that imposition, in practices, in games of exclusion/inclusion of identity and knowledge in the fields of legitimacy, politics and power. Because: "Whatever is known has always seemed systematic, proven, applicable, and evident to the knower. Every alien system of knowledge has likewise seemed contradictory, unproven, inapplicable, fanciful, or mystical” (Fleck 1979: 22). How else can we interpret Foucault's (1984a: 88) claim: "This is because knowledge is not made for understanding; it is made for cutting" - to separate, distribute, classify - to produce the identity in the opposites of this "cutting". It is made as a mechanism for dividing practices (Foucault 1982: 208) 
- through which truth and sense, but also identities could be produced.

Therefore, to "overstep" the locality of genealogical paths mean to go beyond the problem of the identity of subjects into the long history of the pre-subjective identity, which is still "trapped" in the "age-old dependencies" (Habermas 1987: 83). Or, to "move forward", to the post-subjective identity of contemporary global societies. Genealogical paths should lead us to all those scattered and unconnected, still non-European and still non-universalized, but local practices that would shape knowledge and identities.

Even within the geographically firm Europe, in its West, neither identity nor knowledge were anchored for a long time in a common concept: "When he crossed the English Channel, Voltaire sensed that he had entered a different intellectual world. Al that was solid in Paris melted into air in London" (Livingstone 2003, 91). Simultaneously, something completely different was happening - the Republic of Letters. Thus it was possible for an Italian, a Catholic, a Jesuit, a Sinologist, who did not speak Arabic, and a Dutchman, a protestant, an Arabist who did not speak Chinese to understand each other in 1665 in Leiden: "When the two men translated their texts into their common language, Latin, the links between Islam and China became apparent" (Burke 2004: 53).

For many paths of contingencies poured into one great "river of necessity" - with Enlightenment - with the concept of autonomy of knowledge and identity. Before that, genealogy could easily "get lost" in the bundle of parochial paths, just as happened to Averroes when he strove to translate Aristotle into Arabic: "Bounded within the circle of Islam" and thus "trying to imagine what a play is without ever having suspected what a theatre is", Averroes "could never know the meaning of tragedy and comedy" (Bauman 2004: 20)

Genealogy does not seek to discover a country, a language or a law - an origin or cause of identity. If genealogy in its own right gives rise to questions concerning our native land, native language, or the laws that govern us, its intention is to reveal the heterogeneous systems which, masked by the self, inhibit the formation of any form of identity (Foucault 1984a: 95).

Our knowledge, just like our identities, was born in struggles and resistance. There is a constant dialectic tension between knowledge and identity, between the European and non-European, between people in Europe and outside of Europe, between a common history and our "local" histories: "The European space has grown to the extent that it is no longer possible to say what is national and what is European" (Delanty 2005: 53).

Odysseus - this great wanderer - is so "deeply cut" into the body of European identity, because he brings the story of a great transformation. He leaves as a warrior but his return is a paradigm of a research adventure of knowledge creation. Is this matrix repeated by Alexander who leaves as a warrior and turns his quest into an expedition? "Alexander is a researcher par excellence... His thirst for knowledge, they say, made him go on his journeys and conquests" (Le Goff 2009: 93-94).

Today, the "old" questions remain open: What is Europe? Who are we, the People of Europe? (Balibar 2004). Where are we Now? Through the answers to these, we could see that identity and knowledge intertwine - maybe in those places where we least expect them - in the field of our historical knowledge and in genealogical analysis.

FUNDING: This research received no external funding.

CONFLICTS OF INTEREST: The authors declare no conflict of interest.

ACKNOWLEDGEMENTS: The draft of this paper is presented at the "European Perspectives on the Sociology of Knowledge" Midterm Conference of the European Sociological Association (ESA), RSO5 - Sociology of knowledge, 26-27 August, TU, Berlin. Main ideas, concepts and some parts of this research are also used in our previous research: Ristić D. and Marinković, D. 2016. The Disciplinary Society and the Birth of Sociology: A Foucauldian Perspective. Družboslovne Razprave 83(XXXII): 29-44 (in English); Marinković, D., Šljukić, S. and Ristić, D. 2014. From Genealogy to Geo-epistemology: A turn towards locality of space, time and knowledge. Sociološki pregled (Sociological Review), 48(3): 333-352 (in Serbian).

\section{REFERENCES}

Balibar, Étienne. 2004. We, the People of Europe? Princeton and Oxford: Princeton University Press.

Bauman, Zygmunt. 2004. Identity. Cambridge: Polity Press.

Berger, Peter L. 1966. “Identity as a Problem in the Sociology of Knowledge.” European Journal of Sociology 7(1): 105-115.

Berger, Peter L., and Thomas Luckmann. 1991. The Social Construction of Reality. London: Penguin Books.

Bloch, Marc. 2004. Feudal Society (I). London and New York: Routledge.

Bloor, David. 1976. Knowledge and Social Imagery. London and Boston: Routledge.

Braudel, Fernand. 1995. The Mediterranean and The Mediterranean World in The Age of Philip II (I). Berkeley and Los Angeles: University of California Press.

Bufton, Serena. 2004. “Social Class.” Pp. 14-34 in Social Identities: Multidisciplinary Ap proaches, edited by G. Taylor, and S. Spencer. London and New York: Routledge.

Burke, Peter. 2004. A Social History of Knowledge: From Gutenberg to Diderot. Malden: Blackwell Publishers.

Chakrabarty, Dipesh. 2008. Provincializing Europe. Princeton: Princeton University Press.

Clark, William, Jan Golinski, and Simon Schaffer. 1999. “Introduction.” Pp. 3-31 in The Sciences in Enlightened Europe, edited by W. Clark, J. Golinski, and S. Schaffer. Chicago and London: The University of Chicago Press.

Daston, Lorraine. 1999. “The Ethos of Enlightenment.” Pp. 495-504 in The Sciences in Enlightened Europe, edited by W. Clark, J. Golinski, and S. Schaffer. Chicago and London: The University of Chicago Press.

Delanty, Gerard. 1995. Inventing Europe: Idea, Identity, Reality. London: Macmillan Press.

Delanty, Gerard, and Chris Rumford. 2005. Rethinking Europe: Social theory and the implications of Europeanization. London and New York: Routledge.

Delumeau, Jean. 1967. La civilization de la Renaissance. Paris: Éditions Arthaud. 
Durkheim, Émile. 1995. The Elementary Forms of Religious Life. New York: The Free Press.

Elden, Stuart. 2003. “Plague, Panopticon, Police.” Surveillance \& Society 1(3): 240-253.

Fleck, Ludwik. 1979. Genesis and Development of a Scientific Fact. Chicago: The University of Chicago Press.

Foucault, Michel. 1978. The History of Sexuality, Volume I. New York: Pantheon Books.

Foucault, Michel. 1980. “Questions on Geography.” Pp. 63-77 in Power/Knowledge Selected Interviews and Other Writings 1972-1977, edited by C. Gordon. New York: Pantheon Books.

Foucault, Michel. 1981. “The Order of Discourse.” Pp. 48-79 in Untying the Text: A Post-Structuralist Reader, edited by R. Young. Boston: Routledge.

Foucault, Michel. 1982. "The Subject and Power.” Pp. 208-226 in Michel Foucault: Beyond Structuralism and Hermeneutics, edited by H. Dreyfus, and P. Rabinow. Chicago: Chicago University Press.

Foucault, Michel. 1984a. "Nietzsche, Genealogy, History.” Pp. 76-100 in The Foucault Reader, edited by P. Rabinow. New York: Pantheon Books.

Foucault, Michel. 1984b. “What is Enlightenment?” Pp. 32-50 in The Foucault Reader edited by P. Rabinow. New York: Pantheon Books.

Foucault, Michel. 1988a. “Truth, Power, Self.” Pp. 9-15 in Technologies of the Self, edited by H.M. Luther, H. Gutman, and P.H. Hutton. Massachusetts: University of Massachusetts Press.

Foucault, M. 1994a. “Théories et institutions pénales.” Pp. 389-393 in Dits et écrits 1970-1975, Tome II, edited by D. Defert, and F. Ewald. Paris: Gallimard.

Foucault, Michel. 1994a. “L’oeil du pouvoir.” Pp. 195-206 in Dits et écrits 1976-1979 Tome III, edited by D. Defert, and F. Ewald. Paris: Gallimard.

Foucault, Michel. 1994b. “Du gouvemement des vivants.” Pp. 125-129 in Dits et écrits 1980-1988, Tome IV. Paris: Gallimard.

Foucault, Michel. 1995. Discipline and Punish. New York: Vintage Books.

Foucault, Michel. 2002. The Order of Things. London and New York. Routledge.

Foucault, Michel. 2003. The Birth of the Clinic. London and New York: Routledge.

Foucault, Michel. 2006a. History of Madness. London and New York: Routledge.

Foucault, Michel. 2006b. Psychiatric Power. New York: Palgrave, Macmillan.

Habermas, Jürgen. 1972. Knowledge and Human Interests. Boston: Beacon Press.

Habermas, Jürgen. 1987. The Philosophical Discourse of Modernity. Cambridge: Polity Press.

Hall, Stuart. 1996. “Who Needs 'Identity’?” Pp. 1-17 in Questions of Cultural Identity, edited by S. Hall and P. Du Gay. London: Sage Publications.

Hegel, Georg Wilhelm Friedrich. 2001. The Philosophy of History. Kitchener: Batoche Books.

Innerarity, D. 2013. "Power and knowledge: The politics of the knowledge society." European Journal of Social Theory 16 (1): 3-16.

Kant, Immanuel. "An Answer to the Question: What is Enlightenment?" 1784. Retrieved June 20, 2014 http://deakinphilosophicalsociety.com/texts/kant/whatisenlightenment.pdf
Layton, Edwin T. 1974. “Technology as Knowledge.” Technology and Culture 15 (1): 3141.

Le Goff, Jacques. 2005. The Birth of Europe. Oxford: Blackwell.

Le Goff, Jacques. 1993. Intellectuals in the Middle Ages. Oxford: Blackwell.

Livingstone, David N. 2003. Putting Science in its Place: Geographies of Scientific Knowledge. Chicago and London: The University of Chicago Press.

Loader, Colin. 2001. "Puritans and Jews: Weber, Sombart and Transvaluators of Modern Society.” The Canadian Journal of Sociology 26(4): 635-653.

Marinković, Dušan and Ristić, Dušan. 2016. "Foucault's 'Hall of Mirrors': investigation into geo-epistemology.” Geografiska Annaler B: Human Geography 98(2): 83-96.

McCarthy, Doyle E. 1996. Knowledge as Culture. New York: Routledge.

Rifkin, Jeremy. 2004. The European Dream. New York: Tarcher/Penguin.

Ristić, Dušan and Marinković, Dušan. 2016. "The disciplinary society and the birth of sociology: A Foucauldian perspective.” Družboslovne razprave 32(83): 29-45.

Said, Edward W. 1979. Orientalism. New York: Vintage Books.

Shotter, John. 1993. Conversational Realities. London: Sage Publications.

Smith, Adrian. 2013. "Europe and an inter-dependent world: Uneven geo-economic and geo-political developments." European Urban and Regional Research 20(1): 3-13.

Weber, Max. 2005. The Protestant Ethic and the Spirit of Capitalism. London and New York: Routledge.

Weiler, Hans N. 2009. "Whose knowledge matters? Development and the Politics of Knowledge.” Pp. 485-496. in Entwicklung als Beruf, edited by T. Hanf, H.N. Weiler and H. Dickow. Baden-Baden: Nomos.

Wintle, Michael. 2013. “The History of the Idea of Europe: Where are We Now?” Perspectives on Europe 43(1): 8-13.

\section{BIOGRAPHICAL NOTE}

Dušan Marinković is full professor of Sociology at the University of Novi Sad, Faculty of Philosophy, Serbia.

Dušan Ristić is assistant professor of Sociology at the University of Novi Sad, Faculty of Philosophy, Serbia.

OPEN ACCESS: This article is distributed under the terms of the Creative Commons Attribution Noncommercial License (CC BY-NC 4.0) which permits any noncommercial use, and reproduction in any medium, provided the original author(s) and source are credited. 
